\title{
Putting "Cartography" into the History of Cartography: Arthur H. Robinson, David Woodward, and the Creation of a Discipline
}

\author{
Matthew H. Edney \\ 2005. Cartographic Perspectives 51, 14-29. ${ }^{1}$
}

The study of the history of cartography underwent substantial changes in the second half of the twentieth century. In 1960 it was little more than a branch of map librarianship and connoisseurship, an antiquarian backwater with relatively limited academic significance. Yet today, after a dramatic "paradigm shift" in the 1980s, the history of cartography is a widely respected field of study in the Anglophone world. ${ }^{2}$ Scholars across the humanities and social sciences increasingly find the study of maps to be intellectually challenging and the interdisciplinary insights their study generates to be academically rewarding. The most obvious components of this intellectual revolution were J. B. Harley and David Woodward's massive History of Cartography (Harley and Woodward, 1987-2007) and Harley's own polemical and pyrotechnical essays (most reprinted in Harley, 2001). It is understandable that commentators have focused on this dramatic period of reform (Edney, 2005b, 1-17). Yet in doing so they have overlooked earlier and equally important efforts by academic cartographers to reconfigure and extend the study of map history. This essay explores that earlier period

${ }^{1}$ Reprinted from the journal Cartographic Perspectives with permission of the North American Cartographic Information Society and Matthew Edney, who has revised the original.

${ }^{2}$ Fabrikant (2003) properly reminded U.S. scholars that academic cartography is truly an international institution; the same is true for the history of cartography. Even so, my subject matter requires me to concentrate on Anglo-American developments in the study of the history of cartography. 
of reform. In particular, it examines the crucial contributions made by Arthur Robinson and his student, David Woodward, to the formation of the history of cartography as a field of study.

The development after 1945 of cartography as an academic field of study entailed the significant augmentation of existing traditions of map history. Established historical interest in cartography focused on the assessment of map content. Led by Robinson, academic cartographers pursued an "internal" ${ }^{3}$ history of cartography in which they studied past practices and techniques of map production and design. They placed "cartography" front and center within the historical picture. At root, this new approach to cartographic history was an ideological exercise: academic cartographers used their historical studies to define and delimit the very scope and nature of their academic enterprise. Subsequently, academic cartographers legitimated and validated their new position within academia by modeling cartography as a communicative science. Woodward in turn used academic cartography's communicative principles to reformulate the study of the history of cartography, expanding the internal history of cartography into a subject of humanistic significance. That move turned out to be a crucial element in the formation of the new "critical paradigm" of map studies in the 1980s. Thus, it is doubtful that the history of cartography would today occupy such a favorable intellectual position if academic cartographers had not first put "cartography" into the history of cartography.

\section{The Traditional Approach: An Empiricist History of Maps}

It is actually rather misleading to posit a coherent field of study called "the history of cartography" for most of the eighteenth, nineteenth, and twentieth centuries. Rather, a number of professionals, librarians, professors, and lay scholars built a looseknit, international community around a common interest in old maps. This community lacked a unifying identifier: the viscount de Santarém might have coined "cartography" in 1839 to mean the "study of maps," by which he specifically understood old maps, but that label was very quickly appropriated by mapping

${ }^{3}$ After 1970, a generation of self-consciously radical historians of science sought to promote their own scholarly interest - in placing science into social and cultural contexts - by sharply distinguishing it from established scholarship that emphasized the development of scientific ideas as almost pure, abstract forms. They called their own history of science "external" (broad-based, good), the established "internal" (narrowly focused, poor). Yet such an ideologically motivated distinction is impossible to maintain in practice and it has since mellowed into a scheme of classifying scholarship along a continuum constructed between two impossible ideals (the utterly external and the utterly internal). There remains, however, a more restricted use of "internal" - which this essay employs - as a label for histories of science which serve the ideological function of legitimating and justifying the professional preconceptions, institutions, and ideologies of a scientific discipline. (One can thus write a generically internal history of science without being ideologically internal, but not vice versa.) 
professionals for their own endeavors (Harley, 1987, 12). ${ }^{4}$ Although nameless and diffuse, the community of scholars interested in old maps all adhered to a common conceptual foundation: maps are unproblematic, scientific documents of spatial fact. This "empiricist paradigm" had its origins in the eighteenth century. Not coincidentally, this was the era when the first general overviews of map history were written by map makers with intellectual pretensions, such as John Green and Denis Robert de Vaugondy (Harley, 1987, 10-2). Such map makers presented their own work as the modern culmination of the process by which geographical maps had steadily improved in both the quality and quantity of their content. Many map makers have since prefaced their own atlases and textbooks with similarly rhetorical historical overviews that perpetuate the professional field's ideological claims to be a science (notably, Raisz, 1938, 1-70). Such professional desires to place one's work at the forefront of cartographic progress has not, however, promoted the detailed study of particular cartographic episodes.

Detailed historical studies were accomplished by scholars interested in the content of old maps. R. A. Skelton $(1972,5)$ succinctly summarized their motivation: "the content of maps has undergone continuous change through time" and it is "this changing content that gives maps significance as documents for social, economic, and political history." Map scholars fell into three interrelated groups: geographers and historians; librarians and archivists; and, map dealers and collectors. Geographers and historians have been interested in old maps because they can serve as primary sources of information about the past: if the flow of information from the world to the map is unproblematic, then the proper interrogation of an old map will provide spatial information about the past. Santarém, for example, was a diplomat who sought to use old maps to shed light on international boundary disputes. Librarians and archivists, especially those in the large national libraries, have sought to make potential users i.e., geographers and historians -aware of the collections under their control and have accordingly undertaken a great deal of the writing about the history of maps. Furthermore, the standard library practices of selecting maps according to the quality of their content and then of organizing them according to the areas mapped have emphasized the progressive increase over time in the quantity and quality of spatial information and have encouraged the production of regional cartobibliographies and map histories. Finally, dealers and collectors have tended to privilege those maps which were the first to record specific items of spatial information and which therefore serve as markers of the progress of human knowledge and science (Harley, 1987, 1223).

Map history was thus handmaiden to other historical scholarship. As William Cumming (1974, xi) could assert, from a position firmly within this traditional approach to map studies, the task of the map historian was simply to analyze old maps

${ }^{4}$ Author's note: Since this essay was originally published, Van der Krogt (2006) has found that several German geographers coined the term for the map-making profession in the $1820 \mathrm{~s}$. 
so as to generate "historical, geographical, and ethnic information" for use by scholars in other fields. In the 1960s, some scholars sought to formalize the study of old maps by regularizing the contextual information necessary for other scholars to interpret maps properly as historical documents (Edney, 2005b, 19-31; Harley, 1968; Skelton, 1972, 103-7, and 1965). Studies of map content have necessarily led to studies of map projections, land surveying, marine navigation, and the biographies of individual cartographers (Skelton, 1972, 62-3, 90-1). They have also promoted the publication of facsimiles of old maps to allow wider access to otherwise rare materials, often with scholarly introductions to allow historians to interpret those maps properly (Blakemore and Harley, 1980, 33-44; Harley, 1987, 17-9; Skelton, 1972, 73-85, 93-6). Yet whatever their precise concerns, all detailed map studies were founded on the belief in the ineluctably progressive nature of cartographic information.

\section{Arthur H. Robinson: Cartographic Design and the Internal History of Cartography}

A few map scholars did consider the history of the techniques involved in map making, incorporating them into the history of map content so as to construct triumphalist narratives in which maps served as surrogates for progress within Western civilization (e.g., Goode, 1927). The only single-volume history of cartography written to date with an emphasis on cartographic technologies was produced on this basis (Brown, 1949, 1953). Precise studies of mapping techniques did not become common until the establishment after World War II of cartography as a valid academic field of study. Academic cartographers then employed a new, internal history to validate their intellectual concerns. By explicating how cartographers in the past designed and physically made maps, they could locate themselves in a trend-line of progress not in the generation of map content but in the techniques and technologies of map making as an implicitly apolitical endeavor. ${ }^{5}$ The result was the prosecution of an internal history of cartography as a craft and profession in parallel with the more traditional map history.

The crucial figure in the post-1945 establishment of an academic cartography in North America was, of course, Arthur Robinson. ${ }^{6}$ During the war, Robinson had been

${ }^{5}$ See especially the reconfiguration along strictly technological lines of Skelton's $(1972,5)$ empirically judicious statement of cartographic progress by Robinson (1982, 12-13). Tyner (1992, 5) echoed Robinson in her upwardly trending graph of "cartographic activity" over time. See also the two historical summaries created as institutional projects (Kretschmer et al., 1986; Wallis and Robinson, 1987).

${ }^{6}$ Despite the centrality of maps to geographical studies, academic cartography barely existed in the USA before 1945; see McMaster and Thrower (1991) and accompanying essays, including Robinson (1991). For (auto)biographical information, see Robinson (1947, 190-1), Robinson (1979), Ristow (1983), Anonymous (1996), and Cook (2005). 
in charge of the [Office of Strategic Services'] ${ }^{7}$ preparation of maps to inform the decisions of the officials who ran the political side of the war. He had realized that, although map scholarship had hitherto focused almost entirely on the "substantive research" of collecting and accurately reproducing spatial data at large scales, the creation of smaller-scale "specialty" and thematic maps was in fact a design process rooted only in unexamined "convention, whim, and ... ill-founded judgment." After the war, Robinson therefore set out to develop cartographic "design principles based on objective visual tests, experience, and logic"; his agenda featured "the pursuit of research in the physiological and psychological effects of color," the reexamination of accepted conventions, and "investigations in perceptibility and readability in typography" (Robinson, 1947, vii and 10; see also Robinson, 1952, viii and 13). Such research would not only regularize the principles of map design, he argued; it would also prevent the political abuse of maps by unscrupulous propagandists and establish cartography as a properly academic discipline. By the 1970s, Robinson's proselytizing had indeed achieved the formation of a new academic discipline - complete with degree programs and professional journals - rooted in the study of effective design for small-scale, specialized maps (McMaster and McMaster, 2002; Montello, 2002; Robinson, 1979; Robinson et al., 1977; Slocum et al., 2004, 18-32; Wolter, 1975).

Robinson relied extensively on an historical approach to define his vision of a logically rigorous discipline of cartographic design. He rewrote the empiricist paradigm's established historical narrative to make room for his own vision. He did so by asserting that cartography had in fact bifurcated circa 1800: military and civil engineers took over the main line of cartographic progress with their large-scale, national or colonial surveys (the epitome of general-purpose mapping) and remained uninterested in map aesthetics; in contrast, social scientists pursued small-scale cartographies, through which they presented their understandings of how the earth and society functioned, and they began to be implicitly interested in aesthetic and conceptual questions of information presentation (Robinson, 1952, 7-8, and 1947, 1-2). It was within this second trend that Robinson could identify the evolution of "the cartographer" as a design professional (Robinson, 1975, 3). Moreover, this second trend had since 1940 experienced a period of "rapid development," in what was effectively a cartographic revolution as profound as that of the Renaissance, and so needed to be properly institutionalized in centers of national excellence (Robinson, 1982, 12-5, 1976b, and 1952, 3). These points have been inculcated in several generations of students through the introductory chapters of Robinson's crucial textbook, Elements of Cartography (Robinson, 1953, 1-8). ${ }^{8}$

${ }^{7}$ Editors' note: The Office of Strategic Services was the precursor of the Central Intelligence Agency in the USA.

${ }^{8}$ The historical introduction has been repeated, with only slight variations, in the later editions. For similar arguments, see also Cuff and Mattson (1982, 1) and Tyner (1992, 1-18). Slocum et al. (2004, 18-32) provide an interesting variant of the historical preface: their institutional history of U.S. academic cartography culminated in the recent eclipse of cartographic design education by GIS, thereby 
No doubt strongly motivated by his own interest in history - he had majored in History at Miami University, Ohio (Anonymous, 1996, 468) - Robinson also explicated the preconditions of his new discipline with detailed studies of the history of cartography as a craft, and in particular of the history of thematic mapping. He began with three studies of exemplary thematic maps from the nineteenth century: Henry Drury Harness's statistical maps of Ireland from the 1830s (Robinson, 1955); Charles Joseph Minard's cartes figuratives of statistical flows, such as his famous 1869 map of Napoleon's Russian campaign (Robinson, 1967); and, Alexander von Humboldt's highly schematic isothermal map of 1817 (Robinson and Wallis, 1967). ${ }^{9}$ While his purpose in each study was to tell the history of each map designer and their works, he was nonetheless interested in elucidating the effectiveness of their representational strategies and in drawing lessons for current cartographic practice. For example, Robinson and Wallis $(1967,120)$ found that Humboldt's map of isotherms exemplified a truly crucial design principle, previously expressed by Humboldt (1811, Volume 1, cxiii-iv), that "a map ...., overcharged with signs, becomes confused, and loses its principal advantage, the power of conveying at once a great number of relations." Robinson subsequently paid closer attention to the development of the concept of the isoline, whether through the statistical creation of the isopleth or the generalization of measurements through isometric lines (Hsu and Robinsin, 1970, 3-4; Robinson, 1976a, 1971). His historical summa [comprehensive treatise] was, of course, his monograph on Early Thematic Mapping in the History of Cartography, a work committed to the bifurcation of cartographic progress in the early 1800 s, such that "thematic \{i.e., academic\} cartographers had no official connection, and little professional contact, with the makers of general maps \{i.e., surveyors\}" (Robinson, 1982, 18).

Our remembrance of Arthur Robinson as a significant historian of cartography in his own right should not be allowed to obscure his more profound legacy for cartographic history: his advocacy made historical studies a legitimate and central enterprise for the new academic cartographic profession. Many academic cartographers have undertaken internal histories, focusing in particular on thematic mapping (MacEachren, 1979; Castner, 1980) or on cartography's "technological transitions" (Monmonier, 1985). Of particular importance in this respect was Robinson's support for strongly internal historical studies by his own doctoral students, notably Norman Thrower (Thrower, 1978, 1966, 1958), Karen Severud Pearson (Cook, 1995; Pearson 1983, 1980, 1978), and David Woodward (Robinson, 1982, xii). Yet the internal history of the academic cartographers remained largely

presenting an implicit rationale for the book itself as a means to educate GIS-users in the principles of thematic cartography design.

${ }^{9}$ Robinson clearly drew extensively on the internal history that permeated Max Eckert's early and exhaustive manifesto for a critical study of maps and map design. In addition to an initial bibliographical overview of map history studies, Eckert (1921-1925, Volume 1, 24-48, 115-32, 410-97, 2, 244-65, and 430-519 passim [throughout the text]) based each topical section - e.g., map projections, relief depiction, geological mapping, and demographic mapping - on a progressivist overview of the development of that particular aspect of cartographic practice. 
distinct from the older tradition of the history of map content. Some academic cartographers did apply their statistical skills to cartometric studies of map content in order to quantify historical progress (Blakemore and Harley 1980, 54-75; Maling, 1989), but very few sought to reconcile the two sets of historical practice at a conceptual level. Robinson himself did appear to do so once, in the mid-1960s, when he argued that cartography could make a meaningful contribution to a liberal education because "there are few results of man's activities that so closely parallel man's interests and intellectual capabilities as the map." The map is therefore "an ideal device around which to build such a study of man's changing interests \{i.e., content\} and abilities \{i.e., techniques\}"; there was accordingly "as much validity in studying maps as human documents ... as there is in studying the changing attitudes toward romanticism, symbolism, realism, etc., in period literature" (Robinson, 1965, 39-40 and 45). The crucial step of blending the two historical approaches, with the result of promoting the study of maps as "human documents," would be taken by David Woodward.

\section{David Woodward: Map Form and a Humanistic History of Cartography}

Academic cartographers definitely motivated some of the community of map scholars to espouse a broader understanding of their subject matter. Academic cartographers developed several models of cartographic communication during the 1960s in an effort to define themselves as "communication scientists." Regardless of their form (Edney, 2005b, 36-41), these models modified, in principle at least, academic cartography's ideology in two important ways. First, they extended the field's subject matter to encompass the use as well as the design of maps. Second, they collapsed the two streams of mapping endeavor construed by Robinson - the "substantive" and the "specialty" - into a single process common to all maps, whatever their scale and purpose. This even-wider conception of the field seems to have contributed to the manner in which more traditional scholars began in the later 1960s and early 1970s to think in terms of a wider and further reaching history of cartography. Both Skelton $(1972,62)^{10}$ and Armando Cortesão (1969-1971, Volume 1, 4) would advance definitions for a new field of the "history of cartography." Shortly thereafter, Helen Wallis $(1973,252)$ would suggest that historical studies should address maps as part of a larger, cartographic communication system.

David Woodward would serve as the primary interpreter of academic cartography's concerns for map historians. He was always deeply committed to the study of the art and design of maps: he left Britain in 1964 to study with Arthur Robinson not because of Robinson's historical work but because of Robinson's

${ }^{10}$ Skelton (1972) originally comprised a series of essays presented in 1966. As posthumously published, it represents a significant hybridization of traditional and internal approaches to map/cartographic history. 
Elements, the definitive text on cartographic design. As a graduate student, Woodward addressed issues of map design, and especially the aesthetic influences of printing technologies, through historical studies that were necessarily internal in character (Woodward 1970a, b, 1967a, b). He was also interested in the non-historical dimensions of map design; for example, he briefly contemplated developing a postdoctoral research project on the subject of "the psychophysical aspects of map lettering." 11 However, his 1969 appointment to be the Newberry Library's first map curator, and in 1970 to be director of that library's newly created Hermon Dunlap Smith Center for the History of Cartography, ensured that his cartographic interests would be expressed primarily through historical studies. ${ }^{12}$

Inevitably, Woodward saw the history of cartography through the lens of the academic cartography in which he had been trained. He was not impressed. "I am appalled," he wrote to Harley in December 1969, "by the lack of organization reflected merely in the chapter headings of such standard books as Bagrow-Skelton, Tooley, etc." Some "organizational principle" was clearly needed to be imposed on the field to give it structure and discipline. ${ }^{13}$ Harley, who had come to the study of old maps as an historical geographer interested in elucidating their content, had just previously suggested that traditional cartographic studies should be regularized by the application of the historian's critical principles of evidentiary analysis (Harley, 1968; Edney, 2005b, 28-30). Woodward certainly appreciated Harley's desire for intellectual rigor, ${ }^{14}$ but as an academic cartographer he nonetheless held that the desired disciplinary structure could come only from cartography itself. To this end, he used several of the models of cartographic communication - in particular, Koláčný (1969) - to inform his own "suggested framework" for the study of the history of cartography (Woodward, 1974).

With his framework, Woodward tried to encompass all the elements relevant to the study of the entire scope of cartography, balancing the highly abstract and idealized communication models with his more pragmatic experiences in map production: the rows comprised the stages of cartographic communication, from the acquisition of data through their representation and dissemination to their consumption by the map user; the constituent personnel, processes, and products defined the columns. He could then

${ }^{11}$ Woodward to Derek H. Maling, 24 April 1968, Newberry Library, Archives RG 07/07/01.

12 Edney (2005a) and Edney (2005b, Chs. 3-4) provide biographical and bibliographical information.

13 Woodward to Harley, 16 December 1969, Newberry Library, Archives RG 07/07/01, referring to Bagrow (1964) and Tooley (1949).

${ }^{14}$ Woodward, "Center for the History of Cartography: Monthly Report, September 1971," 11 October 1971, Newberry Library, Archives RG 07/07/01, 2, identified Harley as one of several scholars who formed a "new "school' of thought" and who sought to place "the history of cartography ... on a firmer methodological base ... by discussing or demonstrating methodology in substantive work." Woodward also noted that such "ideas are in my own line of thinking." 
graphically indicate the partiality of existing histories of cartography by shading cells representative of the material they dealt with. [...]

Woodward consciously presented his framework as a means to unify the two genres of map studies into a single, coherent field. With columns for both "production" and "product," he could bring together either side of what he saw as the "fundamental distinction between the study of the making of the map and the study of the map itself." Overall, he argued that all the cells in the matrix dealt with aspects of map form, which is to say the proper subject of historical study informed by academic cartography, whereas map content permeated the entire matrix, flowing from one cell to the next. Ultimately, map form and map content were indivisible; ultimately, a single history of cartography could be attained through the subordination of map content to a cartographic framework. Woodward could thus conclude that the history of cartography per se is properly "the study of maps, mapmakers, and mapmaking techniques in their human context through time" (Woodward, 1974, 102 \{quotation\}, 107-8, and 114).

As broad and as encompassing as it was, Woodward's framework did seem to privilege the processes of making maps over those of using maps. As J. H. Andrews pointed out when Woodward first presented the framework at the 1973 international conference on the history of cartography, it could not easily handle the social and cultural institutions and circumstances within which maps were made and, more significantly, in which they were used: cartography's socio-cultural context called for more than just the final row of cells allocated by Woodward (Blakemore and Harley, 1980, 45-53; Woodward, 2001c, 37n, and 1982). Making allowance for this point would have required Woodward to completely reconceptualize his framework and so he made no changes for the published essay. Yet he quickly incorporated this general issue into his thinking and in doing so gave the history of cartography a still firmer foundation as the study of an ineluctably human endeavor. This is evident in a paper he presented to a 1977 symposium in which he laid out his plans for a new research project on sixteenth-century Italian commercial cartography. The detailed analysis of the physical form of maps - the precise techniques of their printing, their paper and its watermarks, the assembly and binding of maps into composite atlases - would shed new light on the commercial practices of the map trade which would in turn shed new light on the nature of cultural production in the Italian Renaissance (Woodward, 2007, 2001b, 1996, 1980). Ultimately, this perspective required the interdisciplinary study of maps, a point to which he alluded in 1977 and which was convincingly validated by the 1980 Nebenzahl Lectures on art and cartography (Woodward, 1987; 1980, 139).

The potency and efficacy of Woodward's conception of the history of cartography as a single field, structured and delimited by contemporary conceptions of cartography as an intellectual and so human endeavor, is evident from his interactions with Brian Harley in the 1970s. Harley had initially developed his cartographic interests in order to assess the worth of eighteenth-century, medium- and large-scale maps of England for historical geographical studies; he had undertaken a number of 
detailed studies of the English map trade, which had produced those maps, and he had become especially interested in the medium-scale topographic maps of North America published by William Faden during the American Revolution. This last project led Woodward to invite Harley to present two lectures in the fourth series of Nebenzahl Lectures, held at the Newberry Library in November 1974, which had as its subject the mapping of the revolutionary war (Harley et al., 1978, 1-78). After the lectures, Woodward prevailed upon Harley to extend his analyses of map production to the uses to which maps were put in the eighteenth century (Harley 1976; Harley et al., 1978, 79-110). It was to accomplish this task that Harley first sought to theorize the nature of cartography, relying on the communication models advanced by academic cartographers to do so (Edney 2005b, 47-50).

Most importantly, Woodward in 1977 persuaded Harley to abandon plans for what Harley envisioned as a four-volume history of the mapping of North America and instead to collaborate with Woodward on a four-volume general history of cartography (Woodward, 2001a, 23-24, 1994, xxiii and 1992). In other words, Harley discarded a plan conceived according to the concerns of the traditional history of map content - in which maps are grouped together and studied simply because they happen to show the same geographical area - in favor of a study that groups together and studies maps according to the common practices and processes by which the maps were made and used. The result, of course, was the multi-volume History of Cartography, a work committed to the study of the cartographic activities within each country rather than to narrating the progressive history of geographical information of each country. Harley's and Woodward's conception was strongly grounded in the goals of an internal history: a "general history of cartography ought," at the very least, they wrote, "to lay the foundations .... for a world view of \{cartography's\} own growth" (Edney 2005b, 5156; Harley and Woodward 1987-2007, Volume 1, xviii).

Yet the conviction that the history of cartography is a humanistic discipline concerned with what are at root human endeavors that are part and parcel of larger socio-cultural trends - which is to say the sort of history that Woodward and Harley consciously set out to establish with the History of Cartography (Woodward, 1985, 69) - is actually incompatible with an internal history of cartography. To understand map making and map use as human endeavors requires consideration of all mapping endeavors and not just those which contributed to the present-day concerns of academic cartography; moreover, it requires the understanding of past cartographic endeavors on their own terms and not as part of a supposedly progressive history of cartographic techniques.

Harley and Woodward thus eventually moved from a history of cartography to a history of cartography. It was to define the intellectual foundations of just such a history that Harley would move in the 1980s beyond models of cartographic communication to engage with linguistics, iconography, the sociology of knowledge, and poststructuralism (Edney 2005b, Chs. 5-7). Harley and Woodward sought to reinvest academic cartography with this newfound humanism when they argued that 
the scope and nature of academic cartography should be defined by historical studies and vice versa (Harley and Woodward, 1989). Yet their argument made little impact on academic cartographers, at least of an older generation, who have rejected Harley's powerful critique as being largely irrelevant to cartographic practices and who want histories that are relevant to academic cartography's present-day concerns (Edney, 2005b, 2-7).

\section{Conclusion}

An historical sensibility and particular historical studies were crucial elements in the formation of the post-1945 academic discipline of cartography. On the one hand, a clear sense of the overall outline of the history of cartographic techniques validated and legitimized the mission of Arthur Robinson and his colleagues to establish map design research as an appropriate field of study within higher education. On the other hand, studies of past cartographic techniques shed important light on the issues of map design and production. The result was the undertaking of what might be called an internal history of cartography. This new history complemented the existing tradition of map studies, which focused on the history of map content, by putting "cartography" into the history of cartography. Both trends of inquiry were implicitly progressivist in nature, the one emphasizing the ineluctable increase in quantity and quality of map data, the other the technological revolutions that have underpinned the craft of cartography.

In reconciling these two distinct approaches, David Woodward followed his academic training to advocate the study of the practices of map making and map use. But by focusing on such practices in the past, where they do not have any necessary connection to those of the present, Woodward understood them as fundamentally human endeavors. His work in the 1970s had a significant impact on the work of Brian Harley, who was forced to put cartography into his own historical map studies. Eventually, the pursuit of the humanistic nature of map making and map use led Woodward to look beyond the disciplinary concerns of academic cartography, no matter how committed he remained to those concerns in his teaching and professional service.

In the mean time, however, Woodward built upon Robinson's work to establish that the history of cartography is, indeed, properly concerned with cartography. Studies of map content have persisted but they are increasingly outmoded and marginal to the field, to the point where Simms and van der Krogt (2008) - neither of whom could be called "radical" - recently argued without irony that the single theme of the 1967 international conference on the history of cartography, "Early Maps as Historical Evidence," was "rather poorly chosen" because it gave "the conference and its papers too much the feeling of a historical geography conference than one properly on the history of cartography." Internal histories of cartography continue also to be written by academic cartographers, but they seem to have generally fallen out of favor 
as academic cartography has been increasingly redefined by digital technologies (Harley and Woodward, 1989). It is the new form of cartographic history which has flourished as an interdisciplinary field. It is thus something of a paradox that Robinson never gave up on the empiricist paradigm that underpinned both traditional map studies and academic cartography (Fremlin and Robinson, 1998), yet he and Woodward lay the foundations for a new, critical paradigm of map studies.

\section{References}

Anonymous. 1996. Robinson, Arthur H. In, Judith Graham (ed.), Current Biography Yearbook 1996. New York: H. H. Wilson, pp. 467-71.

Bagrow, Leo. 1964. The History of Cartography. Trans. D. L. Paisley. London: C. A. Watts.

Blakemore, Michael J. and J. B. Harley. 1980. Concepts in the history of cartography: A review and perspective. Cartographica 17(4), Monograph 26.

Brown, Lloyd A. 1953. Maps: The necessary medium to world progress. Surveying and Mapping 13, 277-85.

Brown, Lloyd A. 1949. The Story of Maps. Boston: Little, Brown \& Co. Repr. New York: Dover, 1979.

Castner, Henry W. 1980. Special purpose mapping in 18th century Russia: A search for the beginnings of thematic mapping. The American Cartographer 7, 163-75.

Cook, Karen Severud. 2005. Arthur H. Robinson (1915-2004). Imago Mundi 57(2), 195-7.

Cook, Karen Severud. 1995. From false starts to firm beginnings: Early colour printing of geological maps. Imago Mundi 47, 155-72.

Cortesão, Armando. 1969-1971. History of Portuguese Cartography. 2 Vols. Agrupamento de Estudos de Cartografia Antiga, 6 and 8. Lisbon: Junta de investigacões do ultramar.

Cuff, David J. and Mark T. Mattson. 1982. Thematic Maps: Their Design and Production. New York: Methuen.

Cumming, William P. 1974. British Maps of Colonial America. Chicago: University of Chicago Press.

Eckert, Max. 1921-1925. Die Kartenwissenschaft: Forschungen und Grundlagen zu einer Kartographie als Wissenschaft. 2 Vols. Berlin: Walter de Gruyter. 
Edney, Matthew H. 2005a. David Alfred Woodward (1942-2004). Imago Mundi 57(1), $75-83$.

Edney, Matthew H. 2005b. The origins and development of J. B. Harley's cartographic theories. Cartographica 40(1/2), Monograph 54.

Fabrikant, Sara Irina. 2003. Commentary on "A history of twentieth-century American academic cartography" by Robert McMaster and Susanna McMaster. Cartography and Geographic Information Science 30(3), 81-4.

Fremlin, Gerald and Arthur H. Robinson. 1998. Maps as mediated seeing. Cartographica 35(1/2), Monograph 51.

Goode, J. Paul. 1927. The Map as a Record of Progress in Geography. Annals of the Association of American Geographers 17(1), 1-14.

Harley, J. B. 2001. The New Nature of Maps: Essays in the History of Cartography. Baltimore: Johns Hopkins University Press.

Harley, J. B. 1987. The map and the development of the history of cartography. In, J. B. Harley \& David Woodward (eds.). The History of Cartography. Volume 1: Cartography in Prehistoric, Ancient, and Medieval Europe and the Mediterranean. Chicago: University of Chicago Press, pp. 1-42.

Harley, J. B. 1976. The map-user in eighteenth-century North America: Some preliminary observations. In, Brian S. Osborne (ed.) The Settlement of Canada: Origins and Transfer; Proceedings of the 1975 British-Canadian Symposium on Historical Geography. Kingston: Department of Geography, Queen's University, pp. 47-69.

Harley, J. B. 1968. The evaluation of early maps: Towards a methodology. Imago Mundi 22, 62-74.

Harley, J. B., Barbara Bartz Petchenik and Lawrence W. Towner. 1978. Mapping the American Revolutionary War. Chicago: University of Chicago Press.

Harley, J. B. and David Woodward. 1989. Why cartography needs its history. The American Cartographer 16, 5-15.

Harley, J. B. and David Woodward (eds.). 1987-2007. The History of Cartography. 3 Vols. \{Vols. 4-6 in preparation.\} Chicago: University of Chicago Press.

Hsu, Mei-Ling and Arthur H. Robinson. 1970. The Fidelity of Isopleth Maps: An Experimental Study. Minneapolis: University of Minnesota Press.

Humboldt, Alexander von. 1811. Political Essay on the Kingdom of New Spain. 4 Vols. Trans. John Black. London: Longman, Hurst, Rees, Orme, and Brown. 
Koláčný, Anton. 1969. Cartographic information: A fundamental concept and term in modern cartography." The Cartographic Journal 6, 47-9.

Kretschmer, Ingrid, Johannes Dörflinger and Franz Wawrik (eds.). 1986. Lexikon zur Geschichte der Kartographie von den Anfängen bis zum ersten Weltkrieg. 2 Vols. Part C of Die Kartographie und ihre Randgebiete: Enzyklopädie. Vienna: Franz Deuticke.

Krogt, Peter van der. 2006. Kartografie of cartografie? Caert-Thresoor 25(1), 11-2.

MacEachren, Alan M. 1979. The evolution of thematic cartography: A research methodology and historical review. The Canadian Cartographer 16(1), 17-33.

Maling, D. H. 1989. Measurements from Maps: Principles and Methods of Cartometry. Oxford: Pergamon Press.

McMaster, Robert B. and Susanna McMaster. 2002. A History of Twentieth-Century American Academic Cartography. Cartography and Geographic Information Science 29(3), 305-21.

McMaster, Robert B. and Norman J. W. Thrower. 1991. The Early Years of American Academic Cartography: 1920-45. Cartography and Geographic Information Systems 18(3), 151-5.

Monmonier, Mark. 1985. Technological Transition in Cartography. Madison: University of Wisconsin Press.

Montello, Daniel R. 2002. Cognitive map-design research in the twentieth century: Theoretical and empirical approaches. Cartography and Geographic Information Science 29(3), 283-304.

Pearson, Karen Severud. 1983. Mechanization and the area symbol: Cartographic techniques in 19th-century geographical journals. Cartographica 20(4), 1-34.

Pearson, Karen Severud. 1980. The nineteenth-century colour revolution: Maps in geographical journals. Imago Mundi 32, 9-20.

Pearson, Karen Severud. 1978. Lithographic Maps in the Nineteenth Century Geographical Journals. Ph.D. thesis. University of Wisconsin-Madison.

Raisz, Erwin. 1938. General Cartography. New York: McGraw-Hill.

Ristow, Walter W. 1983. Cartography and Robinson, then and now. Bulletin of the Geography and Map Division, Special Libraries Association 132, 8-16. 
Robinson, Arthur H. 1991. The development of cartography at the University of Wisconsin-Madison. Cartography and Geographic Information Systems 18, 1567.

Robinson, Arthur H. 1982. Early Thematic Mapping in the History of Cartography. Chicago: University of Chicago Press.

Robinson, Arthur H. 1979. Geography and cartography then and now. Annals of the Association of American Geographers 69(1), 97-102.

Robinson, Arthur H. 1976a. Nathaniel Blackmore's Plaine Chart of Nova Scotia: Isobaths in the open sea? Imago Mundi 28, 137-41.

Robinson, Arthur H. 1976b. Revolutions in cartography. In, Technical Papers of the 36th Annual Meeting of the American Congress on Surveying and Mapping, February, 1976, Washington, D.C.. Falls Church, Va.: American Congress on Surveying and Mapping, pp. 333-9.

Robinson, Arthur H. 1975. Mapmaking and Map Printing: The Evolution of a Working Relationship. In, David Woodward (ed.), Five Centuries of Map Printing. Chicago: University of Chicago Press, pp. 1-23.

Robinson, Arthur H. 1971. The Genealogy of the isopleth. The Cartographic Journal $8(1), 49-53$.

Robinson, Arthur H. 1967. The thematic maps of Charles Joseph Minard. Imago Mundi 21, 95-108.

Robinson, Arthur H. 1965. The potential contribution of cartography in liberal education. Cartographer 2 (1), 1-8.

Robinson, Arthur H. 1955. The 1837 Maps of Henry Drury Harness. The Geographical Journal 121(4), 440-50.

Robinson, Arthur H. 1953. Elements of Cartography. New York: John Wiley \& Sons.

Robinson, Arthur H. 1952. The Look of Maps: An Examination of Cartographic Design. Madison: University of Wisconsin Press.

Robinson, Arthur H. 1947. Foundations of Cartographic Methodology. Ph.D. thesis. Ohio State University.

Robinson, Arthur H., Joel L. Morrison and Phillip C. Muehrcke. 1977. Cartography 1950-2000. Transactions of the Institute of British Geographers ns 2(1), 3-18.

Robinson, Arthur H. and Helen M. Wallis. 1967. Humboldt's map of isothermal lines: A milestone in thematic cartography. The Cartographic Journal 4(2), 119-23. 
Simms, Douglas W. and Peter van der Krogt. 2008. The International Conferences on the History of Cartography: A Short History and Bibliography of Papers / $\left\{2^{\text {nd }}\right\}$ Conference on the History of Cartography, 21-22 September, 1967, London." http://cartography.geog.uu.nl/ichc/1967.html. [Accessed 8 Feb., 2008].

Skelton, R. A. 1972. Maps: A Historical Survey of their Study and Collecting. Chicago: University of Chicago Press.

Skelton, R. A. 1965. Looking at an Early Map. The Annual Public Lecture on Books and Bibliography, University of Kansas, October 1962. University of Kansas Publications, Library Series 17. Lawrence: University of Kansas Press.

Slocum, Terry A., Robert B. McMaster, Fritz C. Kessler and Hugh H. Howard. 2004. Thematic Cartography and Geographic Visualization. $2^{\text {nd }}$ ed. Upper Saddle River, N.J.: Pearson Prentice Hall.

Thrower, Norman J. W. 1978. Edmond Halley and thematic geo-cartography. In, Norman J. W. Thrower (ed.), The Compleat Plattmaker: Essays on Chart, Map, and Globe Making in England in the Seventeenth and Eighteenth Centuries. Berkeley: University of California Press, pp. 195-228.

Thrower, Norman J. W. 1966. Original Land Survey and Land Subdivision: A Comparative Study of the Form and Effect of Contrasting Cadastral Surveys. Association of American Geographers, Monograph 4. Chicago: Rand McNally.

Thrower, Norman J. W. 1958. Original Survey and Land Sub-Division in Rural Ohio. Ph.D. thesis. University of Wisconsin-Madison.

Tooley, R. V. 1949. Maps and Map-Makers. London: B. T. Batsford.

Tyner, Judith. 1992. Introduction to Thematic Cartography. Englewood Cliffs, N.J.: Prentice-Hall.

Wallis, Helen M. 1973. Maps as a medium of scientific communication. In, Józef Babicz (ed.), Studia z Dziejów Geografii i Kartografii [Studies of history of geography and cartography]. Monografie z Dziejów Nauki i Techniki, 87. Wrocław: Polska Akademia Nauk, pp. 251-62.

Wallis, Helen M. and Arthur H. Robinson, eds. 1987. Cartographical Innovations: An International Handbook of Mapping Terms to 1900. London: Map Collector Publications for the International Cartographic Association.

Wolter, John A. 1975. The Emerging Discipline of Cartography. Ph.D. thesis. University of Minnesota. 
Woodward, David. 2007. The Italian Map Trade, 1480-1650. In, David Woodward (ed.), The History of Cartography. Volume 3: Cartography in the European Renaissance. Chicago: University of Chicago Press, pp. 773-803.

Woodward, David. 2001a. Origin and history of The History of Cartography. In, David Woodward, Delano Smith \& Cordell Yee (eds.), Approaches and Challenges in a Worldwide History of Cartography. Barcelona: Institut Cartogràfic de Catalunya, pp. 23-9.

Woodward, David. 2001b. Starting with the map: The Rosselli Map of the World, ca. 1508. In, David Woodward, Delano Smith \& Cordell Yee (eds.), Approaches and Challenges in a Worldwide History of Cartography. Barcelona: Institut Cartogràfic de Catalunya, pp. 71-90.

Woodward, David. 2001c. "Theory" and The History of Cartography. In, David Woodward, Delano Smith \& Cordell Yee (eds.), Approaches and Challenges in a Worldwide History of Cartography. Barcelona: Institut Cartogràfic de Catalunya, pp. 31-48.

Woodward, David. 1996. Maps as Prints in the Italian Renaissance: Makers, Distributors \& Consumers. London: The British Library.

Woodward, David. 1994. "Preface." In, J. Brian Harley \& David Woodward (eds.), The History of Cartography. Volume 2, Book 2: Cartography in the Traditional East and Southeast Asian Societies. Chicago: University of Chicago Press, pp. xxiii-xxvii.

Woodward, David. 1992. A Devon walk: The history of cartography. In, David Woodward (ed.), A Celebration of the Life and Work of J. B. Harley, 1932-1991 [17 March 1992]. London: Royal Geographical Society, pp. 13-5.

Woodward, David (ed.). 1987. Art and Cartography: Six Historical Essays. Chicago: University of Chicago Press.

Woodward, David. 1985. Cartography and design history: A commentary. Design Issues 2(2), 69-71.

Woodward, David. 1982. Response to Blakemore and Harley (1980). Ed. Edward H. Dahl. Cartographica 19(1), 76-7.

Woodward, David. 1980. The study of the Italian map trade in the sixteenth century: Needs and opportunities. In, Cornelis Koeman (ed.), Land- und Seekarten im Mittelalter und in der frühen Neuzeit. Wolfenbütteler-Forschungen 7. Munich: Kraus International, pp. 137-46. 
Woodward, David. 1974. The study of the history of cartography: A suggested framework. The American Cartographer 1, 101-15.

Woodward, David. 1970a. Cerotyping and the Rise of Modern American Commercial Cartography: A Case Study of the Influence of Printing Technology on Cartographic Style. Ph.D. thesis. University of Wisconsin-Madison.

Woodward, David. 1970b. Some evidence for the use of stereotyping on Peter Apian's World Map of 1530. Imago Mundi 24, 43-8.

Woodward, David. 1967a. The Foster Woodcut map controversy: A further examination of the evidence. Imago Mundi 21, 50-61.

Woodward, David. 1967b. Hand-Engraving, Movable Type and Stereotyping: A Study of the Lettering Methods for Woodcut Maps. M.A. thesis. University of Wisconsin-Madison.

Woodward, David, Catherine Delano Smith and Cordell D. K. Yee. 2001. Plantejaments i Objectius d'una Història Universal de la Cartografia [Approaches and Challenges in a Worldwide History of Cartography]. Cicle de conferències sobre Història de la Cartografia, 11. Barcelona: Institut Cartogràfic de Catalunya. 